flavor and dynamic to our work together, in which we never disagreed on substance, despite our very different starting points. We became concerned with the original context of Weber's own quite radical thinking on these topics and with the puzzle of his own sources and context, but also with the peculiar history of its reception, critique, and transformation. The reception history we treated in our first Weber book, the contextual study we detailed in our second. Studying context and, indeed, getting a feel for the salient problems of the time is incvitably a large part of both kinds of projects, and very little of the background reading actually appears in the text.

In working on this period, the period before World War I, Regis discovered the writings of a group of German Jesuits that provided an exposition and critique of the dominant legal and social and political theories of non-Catholic thinkers and also provided a critique of the modernity the theories represented. Regis, who admired great scholarship above all else, became fascinated with these largely lost figures. He began to work on a large work on their critique of modernity and of modern social and economic life. In a way, this project paralleled the Weber reception project in that $\mathrm{Re}$ gis became aware of the innumerable subterranean influences of these thinkers on later Catholic political thinking and especially on papal responses to modernity. But he emphasized what they said rather than its reception. This work will be edited by a friend and published posthumously, and it will be the best possible scholarly memorial. It was a project that employed both his linguistic and intellectual skills as well as deriving its impetus from his own strong intellectual affinity for these thinkers and the issues that these thinkers were concerned with.

Regis once described himself as "persevering, obdurate, and uncompromising." And this was true, as far as it went. In the domains over which he had some control, however, he was quite different. His links with the international community of Catholic scholars and some intense scholarly correspondences, together with a fundamental optimism and generosity toward others, cnabled him to live the life of a scholar rather than a "professional," and served as a reminder that the university could still mean what it meant for Newman. His classes were a model of Socratic dialogue, and he was loved by his students. His Aristotelean sense of virtuous action led him to seek out occasions for political action in which, to use a Weberian phrase, compromises with the devil were unnecessary. He found several, including the Catholic Right to Life Movement and an interesting effort to force universities to follow the wishes of donors. He found some opportunities for action with the university as well, including service on some crucial committees where his stalwart support of scholarly quality was needed. But for the most part, his university political role was restricted to helping students organize, at which he excelled. He rejected the usual compromises of academic life, and at a high price. In this respect he became like the figure from Weber that, I think, always haunted him: the conviction politician who understood politics and sought a political outlet but was denied it by circumstances and by his own moral standards.

Stephen P. Turner University of South Florida

\section{Arvid Pardo}

Arvid Pardo, diplomat, international civil servant, rigorous scholar, and university professor, passed away on June 19, 1999, in Seattle, Washington. He was born in Rome, Italy, on February 12, 1914.

He will be remembered on many accounts, perhaps principally for his innovative proposals relating to the development and reformulation of the international law of the sea. His concern for the equitable sharing of the benefits derivable from the exploitation of mineral resources, including polymetallic nodules, found on and under the deep sea bed and ocean floor (referred to the 1982 Law of the Sea Convention as "the area") led to the provision in Article 136 of that agreement that "The
Area and its resources are the common heritage of mankind."

The acceptance of this key provision of the 1982 treaty followed Ambassador Pardo's continuing and dedicated effort to obtain an overwhelmingly favorable vote for U.N. General Assembly Resolution 2749 (XXV) on December 17, 1970. As the Maltese representative during the early law of the sea negotiations, where he was able to enlist the support of developing countries, as well as to still many of the concerns of the advanced maritime states, he was able to obtain support for the principle, set forth in the General Assembly's Resolution, that "the sea-bed and ocean floor (hereinafter referred to as the area), as well as the resources of the area, are the common heritage of mankind."

Arvid Pardo attended the Collegio Mondragone, Frascati. His graduate studies led to a diploma in diplomatic history from the University of Tours, France, in 1938, and to a doctorate in international law from the University of Rome in 1939). This sense of independence and profound distrust of totalitarian regimes led him to become a member of the underground movement. He was discovered and was imprisoned in Italy and later in Germany between 1940 and 1945. His prison experience produced a life-long concern for the problems of the incarcerated.

With the formation of the United Nations, Dr. Pardo became a member of the early Secretariat, headquartered at Lake Success, New York. His service with the Trustecship Department began in 1945 , where he was a social atfairs officer and later an area officer. From 1945 to 1954 he was the deputy resident representative of the United Nations in Somalia, and from 1963 to 1964 in Ecuador.

When Malta obtained membership in the UN, Dr. Pardo was appointed in 1964 as its permanent representative, which office he held until a change of government in Malta in 1971. The government of Malta appointed Dr. Pardo as its ambassador to the United States and the Soviet Union (1967-71) and as the Maltese High Commissioner to Canada (1969-71). 
From 1971 to 1973 he was the leader of the Maltese delegation to the UN Seabed Committee. These diverse offices and the extremely wide range of his contacts with public officials and private individuals who were interested in an innovative and improved international legal regime for the ocean enabled Ambassador Pardo to play a very influential role in the treaty negotiations. It is not an exaggeration to say that his leadership gave a very positive direction to probably the most successful augmentation of formal international law since 1945.

His critical role in this area resulted in his appointment as coordinator of the ocean studies program at the Woodrow Wilson Center for Scholars in Washington, DC, where he served between 1972 and 1975.

In 1975 Ambassador Pardo joined the faculty of the University of Southern California. At USC he was professor of political science (197581 ), professor of international relations (1981-90), and senior fellow in the Institute of Marine and Coastal Studies (1975-90). As a member of the political science and international relations faculties, he was keenly interested in the research projects of graduate students and served on several Ph.D. committees.

For a period of three years Ambassador Pardo and Professor Carl Q. Christol of the political science faculty combined their legal backgrounds to team-teach graduate seminars. Since the Common Heritage of Mankind principle plays a substantial role in the international law of outer space, approaching this principle from different perspectives allowed for stimulating discussions. One result of the seminar was their joint authorshipof an article entitled "The Common Interest: Tension between the Whole and the Parts," which was published in Macdonald and Johnston's The Structure and Process of International Law: Essays in Legal Philosophy, Doctrine and Theory (1983). His graduate students found Professor Pardo to be a person wholly committed to their professional advancement, who was both demanding of excellence and willing to meet with them on friendly terms to guide and assist them along the way.

Even before Ambassador Pardo had left the service of Malta he had established deep and important contacts with California. In 1971 he became a visiting senior fellow of the Center for the Study of Democratic Institutions in Santa Barbara. Under the leadership of Robert Maynard Hutchins the Center became heavily engaged in studying and promoting the Pacem in Terris program. From this evolved the Pacem in Maribus project under the leadership of Elisabeth Mann Borgese. Under her skillful and dedicated tutelage a series of research projects were undertaken from which important published books and reports emanated. These efforts included the convening of international conferences, including very substantial multidisciplinary participation on the part of leaders of both advanced and developing countries, as well as highly placed personages composing the Club of Rome. The conferences took place in Malta, Japan (including Okinawa), and Algeria.

The Pacem in Maribus activities, in which Ambassador Pardo played a leading role, contributed very materially to the final draft of the 1982 Law of the Sea Convention. He believed firmly that governmental policies and programs could not be successful unless full attention were given by governmental officials to the careful and analytical reports and studies prepared by such institutions as Pacem in Maribus and comparable think tanks.

Thus, he engaged in the work of the Board of the Maltese International Ocean Institute, the Board of Sponsors of the War and Peace Center, the Board of Advisors of the Villanova University Common Heritage Foundation, the Board of Editors of Ocean Yearbook, Board of Editors of Marine Policy, and the Board of Editors of Ocean Management. Among his many other scholarly publications, he coauthored with Elisabeth Mann Borgese The New International Order and the Law-ofthe-Sea (1977).

Among Ambassador Pardo's special honors were the 1982 Paul Hoffman Award of the Society for
International Development, the 1983 Prize of the Third World Foundation, and in 1992 the National Order of Merit of Malta (Knight of Malta) citation.

More than the identifiable prizes and awards he received or might have received was the cherished prize accorded by him to those many associates, friends, and students who benefitted deeply from his humanitarian outlook and from his steady and inspiring commitment to the resolution of mankind's need for disarmament, international development, and a meaningful law for the ocean. For many it may be said that they left the world a better place. The life of Arvid Pardo has placed him very high on any list identifying those who have faithfully and creatively served to ameliorate the wants and needs of humankind

He is survived by his wife, Margit, and children, Christina Pardo Menez, Lars, and David of Scattle, Washington.

\section{Carl Q. Christol University of Southern California}

\section{Tang Tsou}

Tang Tsou usually spoke with a low voice and a measured cadence. He also had a habit of asking his interlocutors whether his English was absolutely correct or as precise as it could be. Yet, even those who met him for the first time were not taken in by his self-effacing demeanor. At one memorable Chicago seminar, an eminent scholar made a condescending remark about China's Hakka minority, unaware that Professor Tsou was himself a Hakka. He promptly interjected, "When it comes to Hakkas, I am not a specialist, but I am a specimen."

When it came to Chinese politics, he was both. As a scholar born and raised in China who was working thoroughly and self-consciously within American political science, he treated Chinese developments as subjects of serious analytical and theoretical concern at a time when China's own apparent extremism and its penchant for radical reversals, as well as the Cold War, posed profound obstacles to doing so. He possessed a unique perspective that 